Journal of Social Sciences 3 (3): 127-133, 2007

ISSN 1549-3652

(C) 2007 Science Publications

\title{
Sample Selection Analysis of Wage Equation for Women In Ondo State Nigeria
}

\author{
${ }^{1}$ Sola Olorunfemi and ${ }^{2}$ Olorunsola E. Olowofeso \\ ${ }^{1}$ Department of Economics, Adekunle Ajasin University, P.M.B. 001, \\ Akungba Akoko, Ondo State Nigeria \\ ${ }^{2}$ Mathematical Sciences Department, Federal University of Technology, \\ P.M.B. 704 Akure, Ondo State Nigeria
}

\begin{abstract}
The study analysis wage equation for women in Ondo State Nigeria, in other to identify the determinant factors of their wages. Data collected from 250 women heads of households through a multi-stage random system technique were analyzed. In order to deal with the zero wage problem associated with those who did not work, various single - equation models were applied. These include wage equation estimated by ordinary least squares; Heckman two-step sample selection model (Heckit) and Maximum Likelihood Estimation. The test on the sample selection coefficients in the Heckman two-step indicates presence of sample selection bias and that the use of the censored sample model would lead to incorrect estimates. It was discovered that the number of children in the household is negatively related to wage of the women in the region. The study suggested that child bearing by women should be reduced as large family size puts pressure on family income and hours of work.
\end{abstract}

Keywords: Sample selection, sample bias, wage equation, incidentally truncated, censored sample model

\section{INTRODUCTION}

The changing role of women and growing awareness of their economic inequality with respect to men have brought international attention to women's issues in the world in recent decades.

Nigeria men and women do not share the same level of economic development. It is therefore, of great interest to know what women's economic positions in Nigeria with different economic development levels and how much their positions have improved with economic development.

A seemingly common belief is that the economic condition of women improves with economic development. This is because economic development improves the population's economy, thereby improving women's absolute economic condition. It also increases the education of women and the rest of society, which raises awareness about women's inferior position, thereby prompting remedial action.

As much as this is a logical belief, the terribly disadvantaged economic position of women in Nigerian economy seems to suggest that economic development is not the only factor, which affects women's economic status. Note that when talking about women's economic position, one always means relative to men. Economic development certainly can improve everybody's economic status, but it does not necessarily improve the position of women relative to men.

Furthermore, if traditional attitudes are deeply rooted in a society, it may take a long time for there to be an acknowledgement of women's subordinate position and attempts to improve it.

Young women, particularly in Nigeria have been socially and economically oppressed for so long that they have low 'aspiration wages' and 'low efficiency' wages. They are prepared to work for low wages for long workweeks and when their productivity declined after a few years of youthful diligence they are replaced by new cohorts ${ }^{[1]}$. According to ${ }^{[2]}$ Nigerian men do not value the economic contribution of their wives. They do not view the women's job and household work as especially taxing. For the most part, Nigerian men consistently take their wives for granted. Moreover, even with economic opportunities men often abandon women, expecting them to carry the financial burden of the family.

There exist a corpus of literature on the wage equation for workers in Nigeria, but with little or no reference to the wage equation for women. This has

Corresponding Author: $\quad$ Dr. Olorunfemi Sola Department Of Economics Adekunle Ajasin University. P.M.B 001, Akungba Akoko,Ondo State Nigeria 
given credence to the assertion that in spite of changes in societal outlook of the capabilities of Nigerian women and her significant contribution to the development process ${ }^{[3]}$, issues in the determinant of wage for workers in Nigeria are rarely treated from the gender point of view. There is therefore an urgent need for studies that look at the determinants of wage for women workers in Nigeria since according to ${ }^{[2]}$ that traditional or tribal society in Nigeria expected women to be significant wage earners $n$ the family.

The objective of this study is to investigate the factors influencing wages of Nigerian women workers.

Many studies have reported that women are ranked normally at the lower end of the occupational hierarchy ${ }^{[4-6]}$. According to them; women's independence by and large depends on their economic independence, which is determined by whether they have paid employment. A few studies have argued that, apart from letting women have more independence, increasing levels of female employment tend to result in women having greater influence on family decisions. Thus, female labour participation is a very important aspect of women's relative economic status ${ }^{[7-10]}$

The fact that women tend to work in the informal sector, family production and volunteer positions means there may be an underestimation of their work in labour statistics and national income accounts, something that have been pointed out frequently in the last two decades ${ }^{[10,11,12]}$. It is very hard to value non-market work in monetary terms.

Some studies suggest that in an agricultural economy, most family members work to some extent if they are physically capable of doing so ${ }^{[7]}$. Nevertheless, this kind of participation does not provide females with independent income, and hence, a higher degree of economic independence.

Therefore, female non-agricultural participation, especially in wage, salary and selfemployed sectors, provides more meaningful measurements from the point of view of improving women's economic status.

Empirical studies often use husband's earnings, schooling, work experience, number of children and other family background as variables to explain female wage earning.

The relationship between wage on one hand, and variables such as age, experience, number of children, working at home, education on the other hand is well documented in the literature. There is robust evidence that real wages increase with both age and tenure $^{[13-16]}$. Many economists would argue that this happens because worker productivity rises with experience. However, there is enough evidence to dispute such idea. Many empirical studies show that older workers earn more than younger workers, even holding productivity constant ${ }^{[17-19]}$.

\section{MATERIAL AND METHODS}

Data were collected from 250 women heads of households in Ondo State through a multi-stage random system technique. 125 women were sampled, each from rural and urban centre in Ondo State. Data collected included total husband earning per month, home production of women, education attainment of women and number of children in the household.

Theoretical Framework and Model Specification: In both classical and neoclassical economic theory, the wage of a female worker can be expressed as a function of education, potential experience, number of children, the time they spend working at home, husband earning and work experience and other shifters to account for dynamics and time trend.

The wage equation formulated for this study is specified as follows:

$\mathrm{wf}=\mathrm{g}\left(\mathrm{ed}, \exp\right.$, noc, he, hp, $\left.w f_{t-1}\right)$

where wf is the wage for female, ed is the education, exp is the potential experience (age), noc is the number of children, he is the husband earning, hp is the home production, $w f_{t-1}$ is lagged regressand which is used to measure the dynamic adjustment of women workers.

The Incidental Truncation Characteristics of the Data: When estimating elasticities, the use of household level micro data is a good way of avoiding the aggregation problem ${ }^{[20]}$. However the use of household micro data is complicated by the econometric problem that arises when some female heads of household receive no wage. Wages are one observed for those who work (wages are unobserved for those who don't work). So information would not be taken from the entire population. Rather, the population would be limited and biased by including only individuals who work. So the data would be nonrandomly selected or incidentally truncated.

In this study, different estimators have been applied to estimate the parameters of the sample selection model. These are Heckman's two-step estimator (Heckit) and the Maximum Likelihood Estimator (MLE). 
In order to correct for the sample bias problem for female who does not work, Heckman's two-step estimation (Heckit) procedure can be applied, as suggested by ${ }^{[21-22]}$. In the first stage, a probit regression is computed in order to estimate the probability that a given female actually work. This regression is used to estimate the inverse Mills ratio $(\lambda)$ for each household, which is used as an instrument in the second regression. The first and second regression equations are given as equations 2 and 3 :

$$
L_{i}=\prec \varpi_{i}+\psi_{i}
$$

Where $\mathrm{i}=$ index for each survey household

$\mathrm{L}=$ Boolean variable indicating membership into a plan

$\prec=$ Vector of variable coefficients to be estimated

$\varpi=$ Vector of independent variables in equation 1

$\psi=$ Error term $\sim \mathrm{N}(0,1)$

$k_{i}=\mathfrak{R} t_{i}+\xi_{i}$

Where $\mathrm{k}=$ satisfaction levels as measured by survey questions

$\mathfrak{R}=$ Vector of variable coefficients to be estimated

$\mathrm{t}=$ Vector of independent variables used in the probit model i.e. equation 2 plus the Inverse Mills Ratio

$\xi=$ error term $\sim \mathrm{N}\left(0, \sigma^{2}\right)$

The sample rule is that $k_{i}$ is observed only when $\mathrm{L}_{\mathrm{i}}$ is greater than zero

$E\left[k_{i} \mid k_{i}\right.$ is observed $]=E\left[k_{i} \mid L_{i}^{*}>0\right]$

$=E\left[k_{i} \mid \psi_{i} \quad>-\varpi^{\prime} k_{i}\right]$

$=t_{i}^{\prime} \mathfrak{R}+E\left[\xi_{i} \mid \psi_{i}>-\varpi^{\prime} \prec_{i}\right]$

$=t_{i}^{\prime} \mathfrak{R}+\mathfrak{I} \sigma_{\xi} \lambda_{i}\left(\lambda_{\psi}\right)$

$=t_{i} \mathfrak{R}_{i}+\mathfrak{R}_{\lambda} \lambda_{i}\left(\lambda_{\psi}\right)$

$$
\begin{array}{r}
\text { Where } \lambda_{\psi}=-\varpi_{i}^{\prime} / \sigma_{\psi} \\
\lambda\left(\lambda_{\psi}\right)=\phi\left(\varpi_{i}^{\prime} / \sigma_{\psi}\right) / \Phi\left(\varpi_{i}^{\prime} / \sigma_{\psi}\right)
\end{array}
$$

Equation 5 is the Inverse Mills Ratio for every household. For notational convenience this is put as

$$
\frac{\phi\left(\prec_{0}+{ }_{\prec_{1} \varpi_{i}}\right)}{\Phi\left(\prec_{0}+\prec_{{ }_{1}} \varpi_{i}\right)}
$$

and where $\phi$, is the density probability function; and $\Phi$ is the cumulative probability function. $\mathfrak{R}$ and $\mathfrak{R}_{\lambda}$ can be estimated by the following equation:

$$
\begin{gathered}
k_{i} \quad \mid L_{i}^{*}>0=E\left[k_{i} \mid L_{i}^{*}>0\right]+\mu_{i} \\
=t_{i}^{\prime} \mathfrak{R}+\mathfrak{R}_{\lambda} \lambda_{i}\left(\lambda_{\psi}\right)+\mu_{i}
\end{gathered}
$$

Where $\mu_{i}$ is heteroscedastic: var

$$
\left[\mu_{i} \mid L_{i}=1, t_{i}, \varpi_{i}\right]=\sigma_{\xi}^{2}\left(1-\mathfrak{J}^{2} \delta_{i}\right)
$$

Least squares regression using incidentally truncated data produces inconsistent estimates of $\mathfrak{R}$. However, the least squares regression of $\mathrm{k}$ on $\mathrm{t}$ and $\lambda$ produces consistent estimators. Omitting $\lambda$ would produce the specification error of an omitted variable.

Unless $\mathfrak{R} \lambda=p \sigma_{\xi}=0$. The hypothesis therefore is to test $\mathrm{H}_{0}: P=0$ using t statistic on $\lambda_{i}$.

For maximum likelihood, recall from equation 2 and 3 that, for the sample selection model, there are two types of observation:

Those where $\mathrm{k}_{\mathrm{i}}$ is observed and we know that $\mathrm{L}_{\mathrm{i}}>0$. For these observations, the likelihood function is the probability of the joint event $\mathrm{k}_{\mathrm{i}}$ and $\mathrm{L}_{\mathrm{i}}>0$. We can write this probability for the ith observation as the following (using Bayes Rule):

$$
\begin{aligned}
& \operatorname{Pr}\left(k_{i}, L_{i}>0 \mid t, \varpi\right)=f\left(k_{i}\right) \operatorname{Pr}\left(L_{i}>0\right. \\
& \left.\mid k_{i}, t, \varpi\right)=f\left(\xi_{i}\right) \operatorname{Pr}\left(\psi_{i}>-\varpi_{i} \prec \mid \xi_{i}, t, \varpi\right) \\
& \frac{1}{\sigma_{1}} \phi\left(\frac{k_{i}-t_{i} \Re}{\sigma_{1}}\right) \cdot \int_{-\varpi \prec}^{\infty} f\left(\psi_{i} \mid \xi_{i}\right) d \psi_{i}
\end{aligned}
$$

$$
\begin{aligned}
= & \frac{1}{\sigma_{1}} \phi\left(\frac{k_{i}-t_{i} \Re}{\sigma_{1}}\right) \cdot \int_{-\sigma \prec}^{\infty} \phi\left(\frac{\psi-\frac{p}{\sigma_{1}}\left(k_{i}-t_{i} \Re\right)}{\sqrt{1-p^{2}}}\right) d \psi_{i} \\
= & \frac{1}{\sigma_{1}} \phi\left(\frac{k_{i}-t_{i} \Re}{\sigma_{1}}\right) \cdot\left[1-\Phi\left(\frac{-\varpi_{i} \prec-\frac{p}{\sigma_{1}}\left(k_{i}-t_{i} \Re\right)}{\sqrt{1-p^{2}}}\right)\right] \\
= & \frac{1}{\sigma_{1}} \phi\left(\frac{k_{i}-t_{i} \Re}{\sigma_{1}}\right) \cdot \Phi\left(\frac{\varpi_{i} \prec+\frac{p}{\sigma_{1}}\left(k_{i}-t_{i} \Re\right)}{\sqrt{1-p^{2}}}\right)
\end{aligned}
$$


Thus the probability of an observation for which we see the data is the density function at the point $\mathrm{k}_{\mathrm{i}}$ multiplied by the conditional probability distribution for $\mathrm{L}_{\mathrm{i}}$ given the value of $\mathrm{k}_{\mathrm{i}}$ that was observed.

Those where $\mathrm{k}_{\mathrm{i}}$ is not observed and we know that $\mathrm{L}_{\mathrm{i}} \leq 0$. For these observations, the likelihood function is just the marginal probability that $\mathrm{L}_{\mathrm{i}} \leq 0$. We have no independent information on $\mathrm{k}_{\mathrm{i}}$. This probability is written as

$$
\operatorname{Pr}\left(L_{i} \leq 0\right)=\operatorname{Pr}\left(\psi_{i} \leq-\varpi_{i} \prec\right) \Phi\left(-\varpi_{i} \prec\right)=1-\Phi\left(\varpi_{i} \prec\right)(10)
$$

Therefore the log likelihood for the complete sample of observations is the following:

$$
\begin{aligned}
& \log \mathbb{R}(\Re, \prec, P, \sigma ; \text { thedata })=\sum_{i=1}^{N_{0}} \log \left[1-\Phi\left(\varpi_{i} \prec\right)\right] \\
& +\sum_{i=N_{0}+1}^{N}\left[-\log \sigma_{1}+\log \phi\left(\frac{k_{i}-t_{i} \Re}{\sigma_{1}}\right)+\log \Phi\left(\frac{\varpi_{i} \prec+\frac{p}{\sigma_{1}}\left(k_{i}-t_{i} \Re\right)}{\sqrt{1-p^{2}}}\right)\right] \quad(11)
\end{aligned}
$$

Where there are No observations where we don't see $\mathrm{k}_{\mathrm{i}}$ and $\mathrm{N}_{1}$ observations where we do $\left(\mathrm{N}_{0}+\mathrm{N}_{1}=\mathrm{N}\right)$. The parameter estimates for the sample selection model can be obtained by maximizing this likelihood function with respect to its arguments. These estimates will be consistent and asymptotically efficient, under the assumption of normality and homoskedasticity of the uncensored disturbances.

\section{RESULTS AND DISCUSSION}

In order to have a consistent result, OLS, Heckman's two-step and maximum likelihood estimators' results are compared. When we compared these various measures of fit in this study, we discuss only the plausible that favour the methods.

In virtually all of the sampling results, the Heckman's two-step has smaller mean squared prediction error (MSPE) of 1.035, 0.719 and 0.961 in Tables 1, 2 and 3 indicating the stability of the Heckman two-step estimatior relative to the other estimators for both the whole vector of estimated parameter and of the slope parameter. The MSPE for OLS is lower than that of MLE, but does not otherwise provide significantly better results than the MLE. In all the Heckman's 2-step has the lowest mean squared prediction error, thus exhibiting the highest level of stability from sample to sample. Further, result from the study shows that the ' $t$ ' statistics test on the sample selection coefficient in the Heckman's 2-step indicates presence of sample selection bias the values are 0.238 (2.211), 0.516 (2.588) and 3.721 (4.116). In other terms, since the hypothesis of sample selection bias is accepted, use of the censored sample model (OLS) would lead us to incorrect estimates for the valuation of wage equation for women in Nigeria. Following ${ }^{[23]}$ that the $\beta, \rho$, and $\sigma$ generated from Heckman 2-step are consisted but not efficient because the conventional standard error estimates are inconsistent and that the regression is intrinsically heteroskedastic due to the selection and that it does not impose the restriction of $|\rho| \leq 1$ The MLE is used along with the 2-step.

Household in Ondo State (urban and rural): All the estimators indicate that there is positive relationship between education and the wage collected by women in Ondo State. That is a $1 \%$ change in education will lead to $41 \%(0.415)$ change in wage earning. Meaning that if education increases with $1 \%$ then wage will increase with $41 \%$. The result under the maximum likelihood estimator also gave positive relationship as under the 2step. The result also reveals that, the wage of women tends to increase substantially as they accumulate work experience. This is so as it is reported in both the 2-step and MLE that a $1 \%$ change in work experience for women in the sampled area is accompany with the positive return of $0.024(24 \%)$ and $0.519(51.9 \%)$ in the estimators respectively. In both the 2-step and MLE and in fact in all other estimators, result confirms that there is a negative relationship between the women wage earning and number of children reared in the household. A $1 \%$ increase in the number of children born to a household will affect the wage earning ability of women in Ondo State. That is it will reduce women wage earning by $14.5 \%$ as it is reported for MLE in Table 1. In this study, results reveal that there is a positive relationship between household earning and women wage as it is shown in all the results from different estimators display in Table 1. This disagree with the study of ${ }^{[24]}$ that an increase in husband wage will affect woman wage. This is so according to him that woman stay at home for home production as husband earning increases.

Results from the finding show that there is a negative relationship between woman wage earning and home production. The 2 -step model indicates that a $1 \%$ increase in woman home production will reduce her wage earning ability by $0.046(4.6 \%)$. In the result, the 
Table 1: Wage Equation for Women Heads of Household in Ondo State Nigeria

\begin{tabular}{|c|c|c|c|c|c|c|}
\hline & OLS & Heckman 2-step & MLE & $\begin{array}{lr}\text { Heckman } & \text { 2-step } \\
\text { with } & \text { no } \\
\text { restriction } & \\
\end{array}$ & $\begin{array}{l}\text { MLE with } \\
\text { restriction }\end{array}$ & no \\
\hline Constant & $\begin{array}{l}1.908 \\
(4.31)\end{array}$ & $\begin{array}{l}1.917 \\
(2.03)\end{array}$ & $\begin{array}{l}2.07 \\
(3.16)\end{array}$ & $\begin{array}{l}1.931 \\
(5.07)\end{array}$ & $\begin{array}{l}1.773 \\
(2.03)\end{array}$ & \\
\hline edu & $\begin{array}{l}0.0117 \\
(1.17)^{*}\end{array}$ & $\begin{array}{l}0.415 \\
(2.61) *\end{array}$ & $\begin{array}{l}1.123 \\
(1.11) *\end{array}$ & $\begin{array}{l}0.796 \\
(2.06)^{*}\end{array}$ & $\begin{array}{l}2.313 \\
(1.36)\end{array}$ & \\
\hline $\exp$ & $\begin{array}{l}0.689 \\
(0.99)\end{array}$ & $\begin{array}{l}0.024 \\
(1.51)^{*}\end{array}$ & $\begin{array}{l}0.519 \\
(0.84)^{* *}\end{array}$ & $\begin{array}{l}0.446 \\
(1.12)^{*}\end{array}$ & $\begin{array}{l}0.976 \\
(1.04)^{* *}\end{array}$ & \\
\hline noc & $\begin{array}{l}-0.117 \\
(2.11)\end{array}$ & $\begin{array}{l}-0.164 \\
(3.41)\end{array}$ & $\begin{array}{l}-0.145 \\
(2.13)^{*}\end{array}$ & $\begin{array}{l}-0.340 \\
(1.74)\end{array}$ & $\begin{array}{l}-0.574 \\
(2.09)^{* *}\end{array}$ & \\
\hline he & $\begin{array}{l}0.571 \\
(3.21)^{*}\end{array}$ & $\begin{array}{l}0.013 \\
(3.06)^{*}\end{array}$ & $\begin{array}{l}0.617 \\
(2.79)^{*}\end{array}$ & $\begin{array}{l}0.062 \\
(3.15)^{*}\end{array}$ & $\begin{array}{l}0.666 \\
(2.65)^{*}\end{array}$ & \\
\hline hp & $\begin{array}{l}-0.424 \\
(0.71)\end{array}$ & $\begin{array}{l}-0.046 \\
(0.62)^{*}\end{array}$ & $\begin{array}{l}0.514 \\
(0.87)^{*}\end{array}$ & $\begin{array}{l}-0.340 \\
(0.92)^{*}\end{array}$ & $\begin{array}{l}-0.121 \\
(0.76)^{*}\end{array}$ & \\
\hline$W f_{t-1}$ & $\begin{array}{l}0.017 \\
(1.91)\end{array}$ & $\begin{array}{l}0.0153 \\
(2.15)^{* *}\end{array}$ & $\begin{array}{l}0.041 \\
(1.77)^{*}\end{array}$ & $\begin{array}{l}0.114 \\
(2.63)^{* *}\end{array}$ & $\begin{array}{l}0.528 \\
(1.14)\end{array}$ & \\
\hline $\begin{array}{l}\text { Diagnostic } \\
\text { (inverse mills) }\end{array}$ & & $\begin{array}{l}0.238 \\
(2.211)\end{array}$ & & & & \\
\hline Wald & & & 3.037 & & & \\
\hline $\mathrm{R}^{2}$ & 0.67 & 0.69 & 0.59 & & & \\
\hline MSPE & 1.277 & 1.033 & 1.203 & & & \\
\hline $\mathrm{D}-\mathrm{W}$ & 1.89 & & & & & \\
\hline
\end{tabular}

Table 2: Wage Equation for Women Heads of Household in the Urban Part of Ondo State Nigeria

\begin{tabular}{|c|c|c|c|c|c|}
\hline 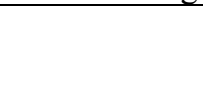 & OLS & Heckman 2-step & MLE & $\begin{array}{lr}\text { Heckman } & \text { 2-step } \\
\text { with } & \text { no } \\
\text { restriction } & \end{array}$ & $\begin{array}{l}\text { MLE with no } \\
\text { restriction }\end{array}$ \\
\hline Constant & $\begin{array}{l}0.826 \\
(3.91)\end{array}$ & $\begin{array}{l}1.040 \\
(1.96)\end{array}$ & $\begin{array}{l}1.531 \\
(2.34)\end{array}$ & $\begin{array}{l}1.447 \\
(2.34)\end{array}$ & $\begin{array}{l}0.967 \\
(4.75)\end{array}$ \\
\hline Edu & $\begin{array}{l}0.716 \\
(1.57)\end{array}$ & $\begin{array}{l}0.152 \\
(1.44)^{*}\end{array}$ & $\begin{array}{l}1.047 \\
(2.17)^{*}\end{array}$ & $\begin{array}{l}0.543 \\
(3.14)^{*}\end{array}$ & $\begin{array}{l}0.112 \\
(2.83)^{*}\end{array}$ \\
\hline $\exp$ & $\begin{array}{l}0.234 \\
(1.11)\end{array}$ & $\begin{array}{l}1.964 \\
(1.65)^{*}\end{array}$ & $\begin{array}{l}0.927 \\
(2.73)^{* *}\end{array}$ & $\begin{array}{l}0.718 \\
(1.06)^{*}\end{array}$ & $\begin{array}{l}1.207 \\
(1.57)^{*}\end{array}$ \\
\hline noc & $\begin{array}{l}-0.382 \\
(0.81)\end{array}$ & $\begin{array}{l}-0.812 \\
(0.92)^{*}\end{array}$ & $\begin{array}{l}-0.262 \\
(0.76)^{*}\end{array}$ & $\begin{array}{l}-0.711 \\
(1.06)\end{array}$ & $\begin{array}{l}-0.331 \\
(0.95)\end{array}$ \\
\hline $\mathrm{He}$ & $\begin{array}{l}0.261 \\
(3.45)^{* *}\end{array}$ & $\begin{array}{l}0.09 \\
(2.46)^{*}\end{array}$ & $\begin{array}{l}0.416 \\
(3.66)^{*}\end{array}$ & $\begin{array}{l}0.577 \\
(2.35)^{*}\end{array}$ & $\begin{array}{l}0.208 \\
(3.12)^{*}\end{array}$ \\
\hline $\mathrm{Hp}$ & $\begin{array}{l}-0.18 \\
(4.32)\end{array}$ & $\begin{array}{l}-0.331 \\
(2.96)\end{array}$ & $\begin{array}{l}0.746 \\
(5.05)\end{array}$ & $\begin{array}{l}-0.464 \\
(4.11)\end{array}$ & $\begin{array}{l}-0.129 \\
(6.22)\end{array}$ \\
\hline $\mathrm{Wf}_{\mathrm{t}-1}$ & $\begin{array}{l}0.624 \\
(6.53)^{*}\end{array}$ & $\begin{array}{l}0.741 \\
(5.98) *\end{array}$ & $\begin{array}{l}0.534 \\
(6.66)^{*}\end{array}$ & $\begin{array}{l}0.444 \\
(11.04)^{*}\end{array}$ & $\begin{array}{l}0.158 \\
(9.75)^{*}\end{array}$ \\
\hline $\begin{array}{l}\text { Diagnostic } \\
\text { (inverse mills) }\end{array}$ & & $\begin{array}{l}0.516 \\
(2.2588)\end{array}$ & & & \\
\hline $\begin{array}{l}\text { Wald } \\
\mathrm{R}^{2} \\
\text { MSPE } \\
\text { D-W }\end{array}$ & $\begin{array}{l}0.71 \\
1.007 \\
1.77\end{array}$ & $\begin{array}{l}0.74 \\
0.719\end{array}$ & $\begin{array}{l}2.897 \\
0.67 \\
0.962\end{array}$ & & \\
\hline
\end{tabular}

Note: The asymptotic standard errors are in parenthesis under the estimate while the ' $t$ ' statistics are in brackets under the inverse mills estimates. * Significant at $5 \%$,** significant at $1 \%$

Source: Computed from data obtained from field survey, 2006 
Table 3: Wage Equation for Women Heads of Household in the Rural Part of Ondo State Nigeria

\begin{tabular}{|c|c|c|c|c|c|}
\hline & OLS & Heckman 2-step & MLE & $\begin{array}{lr}\text { Heckman } & \text { 2-step } \\
\text { with } & \text { no } \\
\text { restriction } & \\
\end{array}$ & $\begin{array}{l}\text { MLE with no } \\
\text { restriction }\end{array}$ \\
\hline Constant & $\begin{array}{l}0.758 \\
(1.74)\end{array}$ & $\begin{array}{l}1.559 \\
(2.52)\end{array}$ & $\begin{array}{l}2.212 \\
(3.12)\end{array}$ & $\begin{array}{l}1.103 \\
(1.16)\end{array}$ & $\begin{array}{l}2.053 \\
(2.81)\end{array}$ \\
\hline Edu & $\begin{array}{l}-0.597 \\
(3.14)\end{array}$ & $\begin{array}{l}-0.360 \\
(2.37)^{* *}\end{array}$ & $\begin{array}{l}-0.271 \\
(1.96)^{*}\end{array}$ & $\begin{array}{l}-0.421 \\
(1.37)^{*}\end{array}$ & $\begin{array}{l}-0.551 \\
(2.16)\end{array}$ \\
\hline $\exp$ & $\begin{array}{l}0.699 \\
(5.21)\end{array}$ & $\begin{array}{l}0.116 \\
(4.36)\end{array}$ & $\begin{array}{l}0.718 \\
(3.32)\end{array}$ & $\begin{array}{l}0.611 \\
(3.44)\end{array}$ & $\begin{array}{l}0.367 \\
(4.11)\end{array}$ \\
\hline noc & $\begin{array}{l}0.106 \\
(0.94)^{*}\end{array}$ & $\begin{array}{l}0.3156 \\
(1.02)^{*}\end{array}$ & $\begin{array}{l}0.214 \\
(0.56)^{*}\end{array}$ & $\begin{array}{l}0.412 \\
(1.41)^{*}\end{array}$ & $\begin{array}{l}0.393 \\
(2.01)^{*}\end{array}$ \\
\hline $\mathrm{He}$ & $\begin{array}{l}0.146 \\
(1.18)\end{array}$ & $\begin{array}{l}0.387 \\
(2.21)\end{array}$ & $\begin{array}{l}0.414 \\
(3.44)\end{array}$ & $\begin{array}{l}0.118 \\
(2.94)\end{array}$ & $\begin{array}{l}0.252 \\
(3.10)\end{array}$ \\
\hline Hp & $\begin{array}{l}0.117 \\
(1.06)\end{array}$ & $\begin{array}{l}0.419 \\
(0.74)^{*}\end{array}$ & $\begin{array}{l}0.627 \\
(0.89)^{* *}\end{array}$ & $\begin{array}{l}0.167 \\
(1.44)^{*}\end{array}$ & $\begin{array}{l}0.212 \\
(1.62)^{*}\end{array}$ \\
\hline $\mathrm{Wf}_{\mathrm{t}-1}$ & $\begin{array}{l}1.602 \\
(3.12)\end{array}$ & $\begin{array}{l}0.061 \\
(2.51)\end{array}$ & $\begin{array}{l}0.518 \\
(3.01)\end{array}$ & $\begin{array}{l}1.719 \\
(2.05)\end{array}$ & $\begin{array}{l}2.140 \\
(3.41)\end{array}$ \\
\hline $\begin{array}{l}\text { Diagnostic } \\
\text { (inverse mills) }\end{array}$ & & $\begin{array}{l}3.721 \\
(4.1161)\end{array}$ & & & \\
\hline $\begin{array}{l}\text { Wald } \\
\mathrm{R}^{2} \\
\text { MSPE } \\
\text { D-W }\end{array}$ & $\begin{array}{l}0.56 \\
1.417 \\
1.92 \\
\end{array}$ & $\begin{array}{l}0.58 \\
1.018\end{array}$ & $\begin{array}{l}3.772 \\
0.53 \\
1.211\end{array}$ & & \\
\hline
\end{tabular}

lagged value for wage is significant in both the 2-step and MLE estimators suggesting dynamic adjustment of women. From table 1, the wage model show very good fit with $\mathrm{R}^{2}$ mostly in the high 69 and 57 percent in both 2-step and MLE. Durbin - Watson (D-W) statistics suggest the absence of serial correlation. Also some of the parameters are theoretically consistent, giving the expected positive and negative signs.

Household in urban Ondo state: Next we analyse wage equation for women in Ondo State. Table 2 presents result for this analysis. Change in education, experience, husband earning and lagged in women's wage still have positive impact on women wage generally, while number of children in household and home production still continue to have negative impact on wage collected by women. of particular note here is the inverse relationship between wage and home production. The result in this study accords the study of ${ }^{[24]}$ carried out in far away Indian that women's time for home production tends to fall when her wage increases. The only significant different now is that the goodness of fit $\left(\mathrm{R}^{2}\right)$ is higher now in all the sub-models, as the coefficients are now $74 \%$ for 2 -step and $67 \%$ for
MLE. For instance, in the 2-step $74 \%$ of the total systematic variation in the women's wage is accounted for by the explanatory variables.

Household in Rural Ondo State: Finally we analyse the wage equation for women in the rural Ondo State. From the result, it is surprisingly found out that education now has negative relationship with women's wage in all the sub models. For instance, in the Heckman 2-step, the result indicates that a $1 \%$ increase in the education attainment of women will reduce their wage by $0.36(36 \%)$. This might not be unconnected with the unavailability of paid jobs in the rural areas of Ondo state. Also important to note is the positive relationship between wage and number of children in the household in the rural part of Ondo State meaning that a $1 \%$ increase in the number of children in a household will lead to $31.5 \%$ increase in wage. Result also shows that there is a positive relationship between home production and wage earning for women, why all these are so is subject to further study.

Policy Implications and Conclusion: The study empirically analysed wage equation for women in Ondo State Nigeria. The followings are the findings and possible areas of intervention.

1. As wage earning is positively related to woman education in Ondo State, government should encourage women to attend school and 
when it is necessary try to convince them to be educated. This is important as women education can play a positive role in making them to pick up paid job just as men. This is so, because, as women's education improves their awareness of the importance of independence rises.

2. The number of children in the household is negatively related to wage in the Ondo State pooled together. However this is not so when the sample from rural part of Ondo State was considered. These findings appear to be clumsy. The women in the household should in collaboration with their husbands ensure that there is a reduction in the family size. It has been noted that large family size puts pressure on family income and hours of work.

3. In the rural part of Ondo State there is extensive unemployment among women. This explains why there is a negative relationship between women wage and education. Government should therefore set up cottage industries where it will be possible for women to secure paid job.

In this way, it is hoped that a gradual elimination of discrimination on sex lines in wage earning in Nigeria would be ensured, and according to ${ }^{[25]}$, the full capabilities of women in Nigeria will remain under-utilized and the benefit of development unequally distributed unless society at large and its agent, the government are determined to developed this potential and are sympathetic to the problems of combining home and work responsibilities.

\section{REFERENCES}

1. Standing G. 1989. Global Feminisation Through Flexible Labour, World Development 17(7), 1077-1095

2. Alyssa Quails 2001. Women in Nigeria today Website: www.postcolonialweb.org/nigeria/contwomen.html

3. Osiruemu, E. 2004. Women in the Trade Union Movement in Nigeria: The constraints. A Journal of Culture and African Women Studies 6, 1-11

4. Levin, D.A. 1991 Women and Industrial Labour Market in Hong-Kong: Participation and Perceptions in Status Influence in Third World Labour Market, Scovilled, J.G. (ed) Berlin: Alter de Gruyler.

5. Anker, R. and C. Hein 1986. Sex Inequalities in Urban Employment in the Third World, London Macmillan, 1017

6. International Labour Office 1994. Yearbook of Labour Statistics, Genera: International Labour Office.

7. Standing, G. 1978. Labour Force Participation and Development, Geneva: International Labour Office.

8. Heer, D.M. 1963. Bominence and the Working Wife, in the Employed Mother in America F.I. Nye and L. Hoffuan (Eds) Chicago Rand Mcnally

9. Schultz, T.P. 1990. Women's Changing Participation in the Labour Force.

10. A world perspective, Economic Development and Cultural Change 38, 457-488.
11. Boserup, E. 1970. Women's Role in Economic Development, London; Allen and Unwin.

12. Dixon-Mueller, R. and R. Anker 1988. Assessing Women's Economic Contribution to Development Training in Population, Human Resources and Development Planning, World Employment Programme Paper No. 6 Genera, ILO

13. Beneria L. 1992. Accounting for Women's World. The Progress of Two Decades, World Development, 20(11), 1547-1560.

14. Medoff, J.L. and K.G. Abraham 1980. Experience, Performance and earnings, Quarterly Journal of Economics 95, 703-736.

15. Hutchens, R.M.1989. Seniority, Wages and Productivity. A turbulent decade, Journal of Economic Perspectives 3, 49-64.

16. Attonji, J.G. and N. Williams, 1998. The Effect of Labour Market Experience Job Security and Job Mobility on wage growth, Research in Labour Economics 17, 233-276.

17. Thornton R.J., J.D. Rodger, and M.L. Brookshire, 1997. On the Interpretation of Age Earnings Profiles. Journal of Labour Research 18, 351-365.

18. Hellerstein, J.K, D Neumark and K.R. Troske 1996. Wages, Productivity and Worker Characteristics: Evidence from Plant Level Production Functions and Wage Equations, Journal of Labour Economics 17(3) 409-446

19. Haegeland, T. and T.J Kettle. 1999. The creation and analysis of employer - employee matched data (1999): 231-59, in contribution to Economic Analysis, Vol. 241. Amsterdam, New York and Oxford Elsevier Science, North-Holland.

20. Abowd, J., F Kramorz, and N. Margolia 2000. Highwage workers and high- wage firms, Econometrical 67, 251-333.

21. Chern, W.S; K. Ishibashi, K. Taniguchi, and Y. Tokoyama, 2003. Analysis of the Food Consumption of Japanese Household FAO Economic and Social Development Paper 152, 1-21.

22. Heckman, J.J. 1976. The Common Structure of Statistical Models of Truncation Sample Selection and limited dependent variables and a simple estimator for such models. Annuals of economic social measurement, 5:475-492.

23. Heckman, J.J. 1979. Sample Selection bias as a specification bias. Econometrical, 47:53-161.

24. Olorunfemi, S. and I. A. Ajibefun 2006. Sample Selection Analysis of Household Food Consumption in Southwestern Nigeria Pakistan Journal of Social Sciences Vol.. 4(1) 1-8

25. Malathy, R. 1994. Education and Women's Time Allocation to Non-market Work in an Urban Setting in India; Economic Development and Cultural Change 42, 743-760

26. Fapounda E.R. 1978. "Women at work in Nigeria; Factors Affecting

27. Modern Sector Employment, Damachi, U.G. and Diejomoah, V.P. (Eds). Human Resources and African Development New York Sage Publishers. 